\title{
PENGARUH RASIO FUNDAMENTAL TERHADAP NILAI PERUSAHAAN DENGAN HARGA SAHAM SEBAGAI VARIABEL INTERVENING PADA PERUSAHAAN SUBSEKTOR BATUBARA YANG TERDAPAT DI BEI TAHUN 2017 - 2019.
}

\author{
Barlia Annis Syahzuni \\ Fakultas Ekonomi dan Bisnis Universitas Esa Unggul Jakarta \\ Jalan Arjuna Utara No 9 Kebon Jeruk 11510 \\ barlia.annis@esaunggul.ac.id
}

\begin{abstract}
This research aims to determine empirically the effect of the company's fundamental ratio which in this study is proxied by return on equity (ROE), current ratio (CR), and debt to equity ratio (DER) on the value of the company which is measured using price earning ratio (PER) and also to see whether stock prices affect this relationship. The coal sub-sector companies listed on the Indonesia Stock Exchange for the period 2017 - 2019 are the population chosen in this study. Sampling was done by purposive sampling, obtained 11 companies in the study period that met the data collection criteria, so that the total financial reports collected were 33 audited financial reports. The type of data is secondary data obtained from the official website www.idx.co.id. The analysis method used is multiple regression analysis. The results shown in this study are partially ROE has a positive effect and DER has a negative effect on stock prices, while $C R$ has no effect on stock prices. Simultaneously, the three fundamental ratios have a significant effect on stock prices. Either partially or simultaneously ROE, $C R$, and DER have no effect on firm value. This study shows that stock prices have a significant effect on firm value, but stock prices are not an intervening variable in seeing the relationship between fundamental ratios and firm value.
\end{abstract}

Keywords: Fundamental ratio, stock price, firm value

\begin{abstract}
Abstrak
Penelitian ini bertujuan untuk mengetahui secara empiris pengaruh rasio fundamental perusahaan diproksikan dengan return on equity (ROE), current ratio (CR), dan debt to equity ratio (DER) terhadap nilai perusahaan yang diukur menggunakan price earning ratio (PER), dan juga untuk melihat apakah harga saham mempengaruhi hubungan ini. Perusahaan sub sektor batubara yang terdaftar di Bursa Efek Indonesia periode 2017 - 2019 menjadi populasi yang dipilih dalam penelitian ini. Pengambilan sampel dilakukan secara purposive sampling, dan diperoleh 11 perusahaan pada periode penelitian yang memenuhi kriteria pengumpulan data, sehingga total laporan keuangan yang terkumpul sebanyak 33 laporan keuangan teraudit. Jenis data adalah data sekunder yang diperoleh dari situs resmi www.idx.co.id. Metode analisis yang digunakan adalah analisis regresi berganda. Hasil yang ditunjukkan dalam penelitian ini adalah secara parsial ROE berpengaruh positif dan DER berpengaruh negatif terhadap harga saham, sedangkan CR tidak berpengaruh terhadap harga saham. Secara simultan ketiga rasio fundamental tersebut berpengaruh signifikan terhadap harga saham. Baik secara parsial maupun simultan ROE, CR, dan DER tidak berpengaruh terhadap nilai perusahaan. Penelitian ini menunjukkan bahwa harga saham berpengaruh signifikan terhadap nilai perusahaan, tetapi harga saham bukanlah variabel intervening dalam melihat hubungan antara rasio fundamental dan nilai perusahaan.
\end{abstract}

Kata Kunci: Rasio Fundamental, harga Saham, nilai perusahaan 


\section{Pendahuluan}

Laporan keuangan disamping sebagai sarana penyampaian informasi tentang kinerja keuangan suatu perusahaan, juga sebagai sarana pertanggungjawaban manajemen atas pengelolaan aset milik perusahaan. Laporan keuangan yang berkualitas adalah laporan keuangan yang menghasilkan informasi yang mencerminkan keadaan perusahaan yang sebenarnya. Ini yang diharapkan oleh para pengguna informasi laporan keuangan tersebut. Informasi yang disajikan dalam laporan keuangan cenderung menjadi perhatian utama para investor dan kreditur.

Investor sangat berminat untuk berinvestasi pada perusahaan subsektor batu bara, karena dengan tingginya kebutuhan batu bara di sinyalir menjadi alasan baiknya kinerja keuangan perusahaan batu bara sehingga dapat memberikan keuntungan yang diharapkan didapat investor. Seperti dikutip pada laman PLN batubara, bahwa selain menjadi sumber energi pembangkit tenaga listrik, batu bara juga memiliki banyak kegunaan seperti menjadi salah satu energi yang dapat menghasilkan suatu produk gas, batubara juga mendukung berbagai seperti alumunium, baja, semen, kertas, dan bahan bakar cair (PLN, n.d.).

Akhir-akhir ini harga saham sejumlah perusahaan barubara mengalami penurunan yang cukup mengkhawatirkan. Penurunan harga batubara disinyalir menjadi salah satu faktor dibalik penurunan harga sahamnya (Kurniawan, 2018). Analisis yang banyak digunakan untuk menentukan nilai sebenarnya dari saham terdapat dua jenis yaitu analisis fundamental dan analisis teknikal (Hartono, 2016). Dalam penelitian ini analisis yang digunakan yaitu analisis rasio fundamental untuk mengetahui faktor yang dapat meningkatkan harga saham. Adapun faktor-faktor yang akan diteliti terhadap harga saham yaitu profitabilitas, likuiditas, dan solvabilitas. Penelitianpenelitian terdahulu telah banyak dilakukan untuk melihat pengaruh profitabilitas, likuiditas dan solvabilitas terhadap harga saham, termasuk oleh Laily, S., \& Izzati (2020) dengan judul penelitian "The Impact of Profitability, Leverage and Dividend on the Share Price of Food and Beverage Sector in Malaysia" yang kemudian dijadikan rujukan dalam penelitian ini.

Namun demikian yang membedakan dengan penelitian ini adalah adanya variable nilai perusahaan yang dijadikan varibel dependen, dan menggunakan harga saham sebagai variabel intervening dalam hubungan pengaruh rasio fundamental dengan nilai perusahaan. Serta obyek penelitian dan rentang waktu yang berbedar. Perusahaan subsector batubara yang dijadikan obyek dalam penelitian ini karena berdasarkan data dari Badan Pusat Statistik (BPS) tahun 2019, bahwa terdapat 5 sekltor yang menjadi yang berkontribusi terhadap produk domestik bruto (PDB), dan sector pertambangan adalah salah satunya. Pada sektor pertambangan minerba, sub sektor Batubara merupakan penopang utama PNBP dengan kontribusi sebesar $80 \%$ (Meilanova, 2020). Hal tersebut yang membuat peneliti tertarik pada perusahaan pertambangan sub sektor Batubara.

Penelitian ini bertujuan untuk melihat secara empiris pengaruh rasio fundamental terhadap harga saham dan nilai perusahaan pada perusahaan sub sector batubara yang terdaftar di Bursa efek Indonesia periode 2017 - 2019.

Penelitian ini akan memberikan pengetahuan kepada pembaca juga stakeholder untuk dapat mengetahui rasio fundamental yang harus menjadi perhatian dalam melihat kinerja dan nilai perusahaan.

\section{Teori Signaling}

Tindakan yang diambil perusahaan untuk memberi petunjuk kepada investor mengenai apa yang sudah dilakukan perusahaan untuk merealisasikan keinginan pemilik, juga untuk memberikan informasi kepada investor tentang perkembangan perusahaan (Eungene F. Brigham dan Joel F. Houston, 2001). Informasi yang dikeluarkan oleh perusahaan ini penting dan besar pengaruhnya terhadap keputusan investor dan juga pelaku bisnis lainnya. Informasi ini menyajikan gambaran kondisi going concern perusahaan di masa lalu, 
masa kini, maupun masa depan, serta efeknya terhadap perusahaan.

\section{Teori Stakeholder}

Menurut Freeman, teori stakeholder mengidentifikasi kelompok yang merupakan pemangku kepentingan dari suatu perusahaan, dan menggambarkan metode yang mana manajemen dapat memberikan perhatian pada kepentingan kelompok tersebut (Freeman, 1984). Membina hubungan baik dengan para stakeholder merupakan salah satu kunci keberhasilan usaha suatu perusahaan. Yang dikatakan sebagai stakeholder bukan hanya investor dan kreditur, tetapi juga pemasok, pelanggan, pemerintah, masyarakat lokal, karyawan, badan regulator, asosiasi perdagangan, termasuk juga lingkungan hidup sebagai bagian dari kehidupan sosial.

\section{Rasio Fundamental}

Rasio fundamental keuangan dapat dijadikan alat untuk menganalisis layak atau tidaknya suatu perusahaan untuk tempat kita berinvestasi. Lima (5) faktor utama menurut (Kayo, 2012) yang paling penting dalam analisis fundamental saham untuk mengidentifikasi saham saham yang memiliki kinerja keuangan yang baik dan berpeluang besar bagi naiknya harga saham di masa yang akan datang. Ke lima faktor tersebut adalah earning per share (EPS), pertumbuhan pendapatan, pertumbuhan laba operasi, return on equity (ROE), dan debt equity ratio (DER). Kinerja perusahaan diwakili oleh rasio profitabilitas, likuiditas, dan solvabilitas. Investor akan merespon dengan positif apabila ke tiga rasio ini baik (R. Y. Lestari, 2019). Maka penelitian ini akan menggunakan 3 rasio fundamental yaitu ROE, CR dan DER.

\section{Harga Saham}

Menurut Nordiana \& Budiyanto (2013) harga saham merupakan harga jual beli yang sedang berlaku di pasar bursa efek yang ditentukan oleh kekuatan pasar, dalam arti tergantung pada kekuatan permintaan dan penawaran. Berfluktuasinya harga saham pada sektor pertambangan dalam waktu cepat dibandingkan dengan harga saham pada sektor lain menandakan tingginya tingkat risiko yang dihadapi. Investor yang masuk dalam kategori investor agresif akan lebih memilih investasi dalam sektor pertambangan, karena tingginya tingkat risiko yang dihadapi diharapkan mampu memberikan tingkat pengembalian yang tinggi juga (high risk high return) (Latifah \& Suryani, 2020). Dalam penelitian ini harga saham diukur berdasarkan harga penutupan (closing price). Harga saham penutupan (closing price) yaitu harga yang diminta oleh penjual atau harga perdagangan terakhir untuk suatu periode (Nordiana \& Budiyanto, 2013a)

\section{Nilai Perusahaan}

Menurut Harmono, nilai perusahaan merupakan kinerja perusahaan yang dicerminkan oleh harga saham yang terbentuk oleh permintaan dan penawaran pasar modal yang merefleksikan penilaian masyarakat terhadap kinerja perusahaan (Harmono, 2019). Sedangkan menurut Gitman (2006), nilai perusahaan merupakan nilai aktual per lembar saham yang akan diterima apabila aset perusahaan dijual sesuai harga saham (Gitman, 2006).

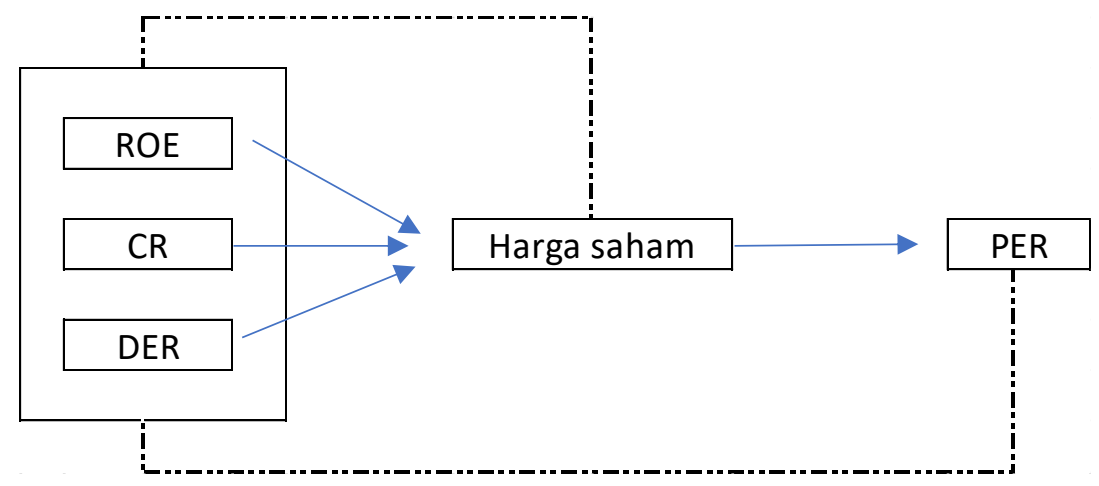


Harga saham yang tinggi akan diikuti dengan nilai perusahaan tinggi juga, dan juga akan meningkatkan kepercayaan pasar terhadap kinerja perusahaan saat ini dan juga pada prospek perusahaan di masa depan. Beberapa metode yang dapat digunakan untuk mengukur nilai perusahaan menurut (Muchlisin Riadi, 2017) adalah price earning ratio (PER), price to book value (PBV), dan Tobin's Q. Penelitian ini menggunakan PER sebagai pengukuran nilai perusahaan.

\section{Hubungan ROE dengan harga saham}

Meningkatnya laba perusahaan merupakan sinyal positif bagi investor. Investor akan sangat tertarik untuk berinvestasi pada perusahaan yang mempunyai laba yang baik. Banyaknya investor yang tertarik untuk berinvestasi akan meningkatkan harga saham. Hal ini telah dibuktikan oleh Laily dan Izzati dalam penelitiannya bahwa profitabilitas berpengaruh terhadap harga saham (Laily, S., \& Izzati, 2020) . Nordiana \& Budiyanto (2013b) juga menyatakan dalam penelitiannya bahwa profitabilitas yang diproksikan dengan ROA berpengaruh terhadap harga saham. Maka dalam penelitian ini diajukan hipotesis:

H1: ROE berpengaruh terhadap harga saham

\section{Hubungan CR dengan harga saham}

Investor dapat melihat kinerja perusahaan dari likuidas perusahaan yang baik. Perusahaan dinilai semakin mampu memenuhi kewajiban lancarnya dengan aset lancar yang dimilikinya, terlihat dari peningkatan current ratio perusahaan, maka perusahaan dapat dikatakan mampu memberikan jaminan yang baik kepada kreditor. Meningkatkan kepercayaan kreditur melalui current ratio akan sangat berpengaruh terhadap harga saham. Seperti ditunjukan oleh Dewi dan Solihin dalam hasil penelitiannya bahwa current ratio berpengaruh negatif dan signifikan terhadap harga saham (Dewi dan Solihin.,2020). Penelitian yang dilakukan oleh wulandari, dkk menunjukan hal sebaliknya bahwa CR tidak signifikan dan berpengaruh negatif terhadap harga saham (Wulandari et al., 2020). Berdasarkan hal tersebut maka diajukan lah hipotesis

$\mathrm{H} 2$ : Current ratio berpengaruh terhadap harga saham

\section{Hubungan DER dengan harga saham}

Debt equity ratio dapat memperlihatkan ratio hutang terhadap modal perusahaan. Semakin besar proporsi hutang dalam pendanaan perusahaan, maka perusahaan yakin dengan going concern perusahaannya, karena ada keyakinan untuk dapat membayar pokok pinjaman beserta bunganya. Hal ini menjadi sinyal positif bagi investor sehingga akan meningkatkan harga saham. Penelitian Latifah \& Suryani mengindikasikan bahwa kebijakan hutang yang di proksikan dengan DER mampu mempengaruhi harga saham (Latifah \& Suryani, 2020). Namun tidak demikian dengan hasil yang di dapat dalam penelitian A. P. Lestari \& Susetyo (2020) yang menyatakan bahwa DER tidak berpengaruh terhadap harga saham. Berdasarkan hal tersebut, maka diajukan hipotesis

H3: DER berpengaruh terhadap harga saham

\section{Hubungan ROE dengan nilai perusahaan}

Nilai perusahaan akan meningkat seiring dengan meningkatnya kemampuan perusahaan dalam menghasilkan laba. Hal ini sangat menarik di mata investor untuk melakukan investasi di perusahaan tersebut. Laba perusahaan merupakan indikator bahwa perusahaan mampu memenuhi kewajiban terhadap stakeholder, maka akan meningkatkan nilai perusahaan yang menunjukan going concern perusahaan. Hal ini telah dibuktikan oleh Chasanah dalam penelitian nya bahwa profitabilitas berpengaruh terhadap nilai perusahaan (Chasanah, 2019). Begitu juga dengan hasil penelitian Oktaviarni (2019) menunjukan hasil yang sejalan. Berdasarkan uraian diatas, maka dalam penelitian ini diajukan hipotesis

H4: ROE berpengaruh terhadap nilai perusahaan 
Hubungan CR dengan nilai perusahaan Likuiditas yang baik yang dapat terlihat dari nilai current ratio nya. Semakin tinggi current ratio maka semakin likuid perusahaan tersebut dan ini semakin meningkatkan nilai perusahaan tersebut. Tingginya nilai current ratio menjadi sinyal yang baik bagi kreditur, karena dengan current ratio yang tinggi berarti perusahaan cenderung lebih dapat memenuhi kewajiban hutang yang jatuh tempo dalam 12 bulan ke depan. Beberapa penelitian yang membuktikan bahwa current ratio berpengaruh terhadap nilai perusahaan, diantaranya adalah penelitian Oktaviarni (2019) dan penelitian R. Y. Lestari (2019). Namun tidak sejalan dengan hasil penelitian Chasanah (2019) bahwa current ratio tidak berpengaruh terhadap nilai perusahaan. Berdasarkan hal tersebut, maka diajukan hipotesis

H5: CR berpengaruh terhadap nilai perusahaan

\section{Hubungan DER dengan nilai perusahaan}

Kebijakan pendanaan juga dapat dijadikan sinyal tentang prospek perusahaan di masa depan seperti yang dijelaskan dalam teori signaling (Miller, Merton H. \& Rock, 1985). Perusahaan yang dinilai mampu bertahan dimasa depan dapat meningkatkan nilai perusahaannya. Perusahaan dengan tingkat hutang tinggi mengindikasikan perusahaan mampu membayar kewajibannya dimasa yang akan datang, sehingga menambah keyakinan investor akan kemampuan perusahaan memberikan pengembalian ke investor, dan ini akan menaikan nilai perusahaan. Namun hal ini bertentangan dengan penelitian Oktaviarni (2019), bahwa DER tidak berpengaruh terhadap nilai perusahaan. Maka hipotesis yang diajukan adalah

H6: DER berpengaruh terhadap nilai perusahaan

\section{Hubungan harga saham dengan nilai perusahaan}

Harga saham yang tinggi menunjukan tinginya minat investor terhadap saham tersebut. Tingginya minat investor karena investor menilai perusahaan positif. Investor dalam berinvestasi menilai kondisi perusahaan dengn melihat harga sahammya. Hubungan antara harga saham dan nilai perusahaan telah dibuktikan oleh beberapa penelitian. Diantaranya adalah penelitian yang dilakukan oleh (Kurnia, 2019) dan (Yuliana, 2020), menghasilkan harga saham berpengaruh terhadap nilai perusahaan. Berdasarkan hal tersebut, maka diajukan hipotesis

H7: Harga saham berpengaruh terhadap nilai perusahaan

\section{Hubungan Rasio fundamental dengan harga saham}

Analisis rasio fundamental dapat memberikan informasi mengenai kondisi keuangan perusahaan, sehingga dapat digunakan sebagai indikator kinerja keuangan perusahaan tersebut. Analisis ini berlandaskan kepercayaan bahwa harga saham sangat dipengaruhi oleh kinerja perusahaan yang tercermin dalam laporan keuangannya. (Daniarto Raharjo, 2013). Jika informasi yang diperoleh baik dan positif maka harga saham perusahaan tersebut diperkirakan akan merefleksikan kekuatan tersebut sehingga harganya akan meningkat. Berdasarkan hal tersebut, maka hipotesis yang diajukan adalah

H8: Rasio fundamental berpengaruh terhadap harga saham

\section{Hubungan Rasio fundamental dengan nilai perusahaan}

Memaksimalkan nilai perusahaan dapaat dicapai jika perusahaan meningkatkan kinerja perusahaannya. Kinerja perusahaan ini dapat terlihat dari rasio fundamental yang diwakili oleh profitabilitas, likuiditas, dan solvabilitas. Penelitian Chasanah (2019) menghasilkan bahwa rasio fundamental yang di proksikan dengan CR, DER, dan ROA secara bersamasama berpengaruh terhadap nilai perusahaan. Hasil yang sama juga di dapat dalam penelitian Oktaviarni (2019). Maka hipotesis yang diajukan adalah

H9: Rasio fundamental berpengaruh terhadap nilai perusahaan 


\section{Metode Penelitian}

Penelitian dengan jenis penelitian kausal komparatif ini mengambil perusahaan subsektor batubara yang konsisten terdaftar di Bursa Efek Indonesia pada periode tahun 2017 - 2019 sebagai populasi. Pada metode penelitian kuantitatif ini menggunakan variabel independen yaitu profitabilitas yang diproksikan dengan $\mathrm{ROE}$, likuiditas yang diproksikan dengan $\mathrm{CR}$, solvabilitas yang diproksikan dengan DER, dan variabel dependen nya yaitu nilai perusahaan yang di proksikan dengan PER, serta variabel intervening harga saham yang diproksikan dengan harga saham saat penutupan.

Teknik pengambilan sampel dilakukan dengan purposive sampling, dimana perusahaan sub sektor Batubara yang terdaftar di Bursa Efek Indonesia (BEI) yang dijadikan sebagai sample adalah perusahaan Batu bara yang memiliki laporan keuangan lengkap yang telah di audit selama periode penelitian yaitu 2017-2019, dan tidak mengalami kerugian selama periode penelitian, serta memiliki harga saham mulai dari Rp 50 sampai dengan Rp 4.000. Berdasarkan kriteria tersebut, maka diperoleh sample sebanyak 11 perusahaan, dengan masing-masing 3 periode laporan keuangan.

Teknik analisis data yang digunakan dalam penelitian ini adalah uji statistik deskriptif, uji asumsi klasik, uji hipotesis, dan uji analisis regresi berganda. Uji asumsi klasik terdiri dari uji normalitas, uji multikolinearitas, uji autokorelasi, dan uji heteroskedastisitas. Uji hipotesis yang dilakukan adalah Uji parsial (uji t) untuk melihat pengaruh variabel independen terhadap variabel dependen secara parsial, dan uji pengaruh simultan (uji f) untuk melihat apakah terdapat pengaruh variabel independen terhadap variabel dependen secara simultan. Juga akan dilakukan uji intervening dengan path analisis, untuk melihat apakah harga saham mempengaruhi hubungan antara variabel independen dengan variabel dependen.

\section{Hasil dan Pembahasan Uji Analisis Deskriptif}

Berdasarkan hasil uji statistik deskriptif diketahui bahwa nilai rata-rata ROE dalam penelitian inni sebesar 22,778, yang berarti bahwa dari perusahaan yang diteliti rata-rata memberikan keuntungan kepada pemilik dari hasil laba perusahaannya tinggi sebesar $22.7 \%$. Rata rata nilai Current ratio (CR) adalah 2,155, yang berarti bahwa perusahaan dalam penelitian ini tergolong likuid dan tidak kesulitan dalam memenuhi kewajiban lancarnya. Nilai rata-rata Debt to equity ratio (DER) sebesar 1.628, yang berarti bahwa dalam rata rata dalam perusahaan yang diteliti ini $62 \%$ nya dibiayai oleh hutang. Nilai minimum Price to Earning Ratio (PER) pada penelitian ini adalah 35 , hal ini berarti perusahaan-perusahaan ini memiliki goingconcern yang baik (Kho, n.d.). Sedangkan harga saham pada penelitian ini berkisar antara harga 50,00 sampai 3970,00 .

\section{Uji Asumsi Klasik}

Uji normalitas pada model ini menggunakan Scatter Plot, dimana plot plot yang dihasilkan menyebar mengikuti alur garis diagonalnya, maka model ini dikatakan memenuhi asumsi normalitas. Nilai VIF (Variance Inflation Faktor) pada model regresi ini kurang dari 10 dengan nilai tolerance lebih dari 0.1. Hal ini berarti tidak terjadi multikolonieritas antar variabel independen dan model regresi ini dikatakan baik. Pada model penelitian ini di dapat korelasi antara variabel independen dengan unstandardized residual memiliki nilai signifikansi $8.3 \%$, yang berarti $>5 \%$, maka dapat disimpulkan bahwa model penelitian ini baik karena bebas dari masalah heteroskedastisitas. Tabel statistik Durbin Watson dengan nilai $\mathrm{k}$ dan $\mathrm{N}$ sesuai dengan penelitian ini menunjukkan bahwa nilai $\mathrm{DL}=$ 1.2358 , nilai $4-\mathrm{DL}=2.7642$, nilai $\mathrm{DU}=$ 1.7245, dan nilai 4-DU $=2.2775$. Model penelitian ini mendapatkan nilai Durbin Watson sebesar 2.008, yang berarti berada diantara DU dan 4-DU, juga terletak diantara DL dan 4-DL. Artinya model penelitian ini bebas dari autokorelasi. 


\section{Uji Hipotesis}

Uji Regresi Parsial (Uji-t)

$\mathrm{H} 1$ : ROE berpengaruh terhadap Harga Saham

Dari hasil ouput spss Uji $t$ variabel ROE terhadap harga saham di dapat nilai t hitung sebesar 4.336 dengan tingkat signifikansi < $5 \%$. Pada tabel statistik untuk signifikansi $0.05 / 2=0.025$, diperoleh hasil $\mathrm{t}$ tabel sebesar 2.03693. Karena tingkat signifikansi $<5 \%$, dan $\mathrm{t}$ hitung $>\mathrm{t}$ tabel, maka Hipotesis 1 di terima. Maka dapat dikatakan bahwa return on equity (ROE) berpengaruh positif dan signifikan terhadap harga saham.

H2: CR berpengaruh terhadap Harga Saham Dari hasil ouput spss Uji $t$ variabel $C R$ terhadap harga saham di dapat nilai t hitung sebesar 0.974 dengan tingkat signifikansi 0.337 . Karena tingkat signifikansi $>5 \%$, dan t hitung < t tabel, maka Hipotesis 2 di tolak. Maka dapat dikatakan bahwa current ratio (CR) tidak berpengaruh positif dan tidak signifikan terhadap harga saham.

H3: DER berpengaruh terhadap Harga Saham

Dari hasil ouput spss Uji $t$ variabel DER terhadap harga saham di dapat nilai t hitung sebesar 4.288 (negatif) dengan tingkat signifikansi $<5 \%$. Karena tingkat signifikansi $<5 \%$, dan $\mathrm{t}$ hitung $>\mathrm{t}$ tabel, maka Hipotesis 3 di terima. Maka dapat dikatakan bahwa Maka dapat dikatakan bahwa debt to equity ratio (DER) berpengaruh negatif dan signifikan terhadap harga saham.

H4: ROE berpengaruh terhadap Nilai Perusahaan

Berdasarkan hasil ouput spss Uji t variabel ROE terhadap nilai perusahaan di dapat nilai t hitung sebesar 1.601 dengan tingkat signifikansi 0.12 . Karena tingkat signifikansi $>5 \%$, dan $\mathrm{t}$ hitung $<\mathrm{t}$ tabel, maka Hipotesis 4 di terima. Maka dapat dikatakan bahwa return on equity (ROE) tidak berpengaruh dan tidak signifikan terhadap nilai perusahaan..

H5: $\quad$ CR berpengaruh terhadap Nilai Perusahaan
Hasil ouput spss Uji t variabel CR terhadap nilai perusahaan menunjukan nilai t hitung sebesar 1.242 dengan tingkat signifikansi 0.22 . Karena tingkat signifikansi $>5 \%$, dan t hitung < t tabel, maka Hipotesis 5 di tolak. Maka dapat dikatakan bahwa current ratio (CR) tidak berpengaruh dan tidak signifikan terhadap nilai perusahaan.

H6: DER berpengaruh terhadap Nilai Perusahaan

Hasil ouput spss Uji t variabel DER terhadap nilai perusahaan menunjukan nilai $t$ hitung sebesar 1.342 (negatif) dengan tingkat signifikansi 0.18 . Karena tingkat signifikansi $>5 \%$, dan $\mathrm{t}$ hitung $<\mathrm{t}$ tabel, maka Hipotesis 6 di tolak. Maka dapat dikatakan bahwa Debt equity ratio (DER) tidak berpengaruh dan tidak signifikan terhadap nilai perusahaan.

H7: Harga saham berpengaruh terhadap Nilai Perusahaan

Hasil ouput spss Uji t variabel Harga saham terhadap nilai perusahaan menunjukan nilai t hitung sebesar 2.889 dengan tingkat signifikansi 0.007. Karena tingkat signifikansi $<5 \%$, dan $\mathrm{t}$ hitung $>\mathrm{t}$ tabel, maka Hipotesis 7 diterima. Maka dapat dikatakan bahwa Harga saham berpengaruh signifikan terhadap nilai perusahaan.

\section{Uji Regresi Simultan (Uji-F)}

H8: ROE, CR, DER berpengaruh simultan terhadap Harga Saham

Berdasarkan hasil ouput spss Uji f variabel independen terhadap harga saham di dapat nilai f hitung sebesar 11.058 dengan tingkat signifikansi < 5\%. Pada tabel statistik diperoleh hasil $f$ tabel sebesar 2.41. Karena tingkat signifikansi $<5 \%$, dan $\mathrm{f}$ hitung $>\mathrm{f}$ tabel, maka Hipotesis 8 di terima. Maka dapat dikatakan bahwa ROE, CR, DER berpengaruh simultan dan signifikan terhadap harga saham.

H9: ROE, CR, DER berpengaruh simultan terhadap Nilai perusahaan

Berdasarkan hasil ouput spss Uji f variabel independen terhadap harga saham di dapat nilai $f$ hitung sebesar 2.079 dengan tingkat signifikansi $>5 \%$. Karena tingkat signifikansi 
$>5 \%$, dan $\mathrm{f}$ hitung < f tabel, maka Hipotesis 9 di tolak. Maka dapat dikatakan bahwa ROE, CR, DER tidak berpengaruh simultan dan tidak signifikan terhadap harga saham.

\section{Uji variabel intervening}

Untuk menguji apakah harga saham benar sebagai variabel intervening dalam model persamaan regresi ini dengan cara menghitung apakah pengaruh tidak langsung variabel independen terhadap variabel dependen lebih besar dari pada pengaruh langsungnya. (Raharjo, 2017)

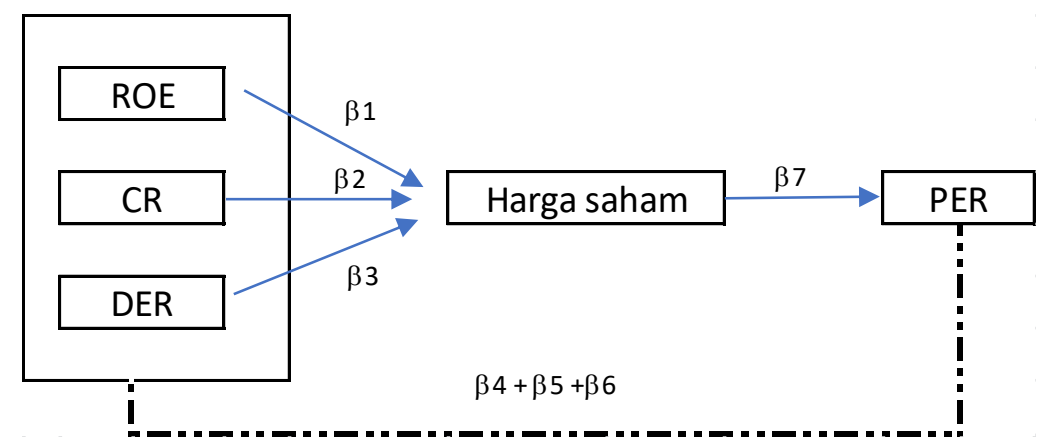

$(B 1 \times \beta 7)+(B 2 \times \beta 7)+(\beta 3 \times \beta 7)>(B 4+\beta 5+\beta 6)$

$(B 1 \times \beta 7)+(B 2 \times \beta 7)+(\beta 3 \times \beta 7)=0.04062$

$(\beta 4+\beta 5+\beta 6)=0,246$

Karena pengaruh tidak langsung variabel independen terhadap variabel dependen lebih kecil dari pada pengaruh langsungnya (0.04062 < 0.246), maka harga saham bukan sebagai variabel intervening dalam model penelitian ini.

\section{Kesimpulan}

Berdasarkan pengujian yang telah dilakukan terhadap hubungan variabelvariabel tersebut pada jenis dan periode yang diteliti, dan berdasarkan uraian diatas, maka dapat diambil kesimpulan bahwa secara parsial ROE berpengaruh positif dan DER berpengaruh negatif terhadap harga saham, sementara CR tidak berpengaruh terhadap harga saham. Dari hasil uji $f$ terihat bawa secara simultan ketiga rasio fundamental tersebut berpengaruh signifikan terhadap harga saham. Hasil yang didapat untuk melihat hubungan rasio fundamental terhadap nilai perusahaan yang di proksikan dengan PER adalah baik secara parsial maupun simultan $\mathrm{ROE}, \mathrm{CR}$, dan DER tidak berpengaruh terhadap nilai perusahaan. Penelitian ini menunjukan bahwa harga saham berpengaruh signifikan terhadap nilai perusahaan, tetapi harga saham bukan sebagai variabel intervening dalam melihat hubungan rasio fundamental terhadap nilai perusahaan. Pada penelitian ini nilai perusahaan diukur menggunakan PER, sedangkan untuk mengukur nilai perusahaan bisa menggunakan PBV dan tobin q. Maka diharapkan pada penelitian selanjutnya dapat menggunakan pengukuran lain dalam melihat nilai perusahaan, juga menggunakan rasio keuangan lain dalam melihat kinerja keuanga, serta dilakukan pada yang berbeda. Bagi investor, hendaknya juga melakukan analisis rasio keuangan agar investasinya lebih aman dan lebih menguntungkan.

\section{Daftar Pustaka}

Chasanah, A. N. (2019). Pengaruh Rasio Likuiditas, Profitabilitas, Struktur Modal Dan Ukuran Perusahaan Terhadap Nilai Perusahaan Pada Perusahaan Manufaktur Yang Terdaftar Di Bei Tahun 2015-2017. Jurnal Penelitan Ekonomi Dan Bisnis, $3(1)$.

https://doi.org/10.33633/jpeb.v3i1.2 
Jurnal Ekonomi : Journal of Economic p-ISSN: 2087-8133 | e-ISSN: 2528-326X

Bagaimana Prospek Emiten Pertambangan Batura?

Daniarto Raharjo, D. M. (2013). Analisis Pengaruh Faktor-Faktor Fundamental Rasio Keuangan Terhadap Perubahan Harga Saham. Diponegoro Journal of Accounting, 2(2).

Eungene F. Brigham dan Joel F. Houston. (2001). Manajemen Keuangan. Erlangga.

Freeman, R. E. (1984). Strategic Management: $A$ Stakeholder Approach.

Gitman, L. J. (2006). Principles of Manajerial Finance. (Internatio). Pearson Education.

Harmono. (2019). Manajemen Keuangan Berbasis Balanced Scorecard (Pendekatan Teori, Kasus, dan Riset Bisnis). Bumi Aksara.

Hartono, J. (2016). Teori Portofolio dan Analisis Investasi (10th ed.). BPFE.

Iriana Kusuma Dewi, D. S. (2020). Pengaruh Current Ratio Dan Net Profit Margin Terhadap Harga Saham. Jurnal IImiah Feasible (JIF), 2(2).

Kayo, E. S. (2012). Analisis Fundamental Saham.

https://www.sahamok.net/analisafundamental-saham/

Kho, B. (n.d.). Pengertian PER dan Rumus PER.

https://ilmumanajemen.com/pengerti an-per-price-earning-ratio-rasioharga-terhadap-pendapatan-rumusper/

Kurnia, D. (2019). Profitabilitas, Kebijakan Dividen dan Harga Saham Terhadap Nilai Perusahaan. Jurnal Akuntansi: Kajian IImiah Akuntansi (JAK), 6(2).

Kurniawan, R. (2018). Harga Batubara Terendah Dalam 6 Bulan Terakhir, http://rivankurniawan.com/2018/12/

11/penurunan-harga-batubara/

Laily, S., \& Izzati, N. I. (2020). The Impact of Profitability, Leverage and Dividend on the Share Price of Food and Beverage Sector in. 12(4), 535540.

Latifah, H. C., \& Suryani, A. W. (2020). Pengaruh kebijakan dividen, kebijakan hutang, profitabilitas, dan likuiditas terhadap harga saham. Jurnal Akuntansi Aktual, Л1). https://doi.org/10.17977/um004v7i1 2020p31

Lestari, A. P., \& Susetyo, A. (2020). Pengaruh NPM, EPS, DER dan PBV Terhadap Harga Saham pada Perusahaan Terdaftar IDX HIDIV20 Dengan DPR sebagai Variabel Intervening. Jurnal IImiah Mahasiswa Manajemen, Bisnis Dan Akuntansi (JIMMBA), 2(2). https://doi.org/10.32639/jimmba.v2i 2.461

Lestari, R. Y. (2019). Pengaruh rasio keuangan terhadap return saham dengan nilai perusahaan sebagai variabel moderating. Management and Business Review, 3(1), 9-22. https://doi.org/10.21067/mbr.v3i1.46 72

Meilanova, D. (2020). Pelaku Tambang Batu Bara Harap Harap Cemas Hadapi Situasi.

https://ekonomi.bisnis.com/read/202 00728/44/1272275/pelaku-tambangbatu-bara-harap-harap-cemashadapi-situasi

Miller, Merton H. \& Rock, K. (1985). Dividend Policy under Asymmetric Information. Thejournal of Finance, $X L$ No.4.

Muchlisin Riadi. (2017). Pengertian, Jenis dan Pengukuran Nilai Perusahaan. 
Kajian Pustaka.Com.

https://www.kajianpustaka.com/2017

/11/pengertian-jenis-dan-

pengukuran-nilai-perusahaan.html

Nordiana \& Budiyanto. (2013a). Pengaruh DER, ROA, dan ROE terhadap harga saham pada perusahaan food and beverage. Journal of Chemical Information and Modeling, 53(9).

Nordiana \& Budiyanto. (2013b). Pengaruh DER, ROA, dan ROE terhadap harga saham pada perusahaan food and beverage. Journal of Chemical Information and Modeling, 53(9), 1689-1699.

Oktaviarni, F. (2019). Pengaruh Profitabilitas, Likuiditas, Leverage, Kebijakan Dividen, Dan Ukuran Perusahaan Terhadap Nilai Perusahaan. Jurnal Akuntansi, 9(1). https://doi.org/10.33369/j.akuntansi. 9.1.1-16

PLN. (n.d.). No Title. https://www.plnbatubara.co.id/

Raharjo, S. (2017). Cara Uji Analisis Jalur [Path Analysis] dengan SPSS Lengkap.

https://www.spssindonesia.com/2017 /03/cara-uji-analisis-jalur-pathanalysis.html

Wulandari, B., Daeli, I. J., Br Bukit, I. K., \& Sibarani, W. N. S. (2020). Pengaruh ROE, CR, TATO, NPM terhadap Harga Saham pada Perusahaan Manufaktur Sub Customer Goods yang terdaftar di Bursa Efek Indonesia. Owner, 4(1).

https://doi.org/10.33395/owner.v4i1. 187

Yuliana, T. (2020). Pengaruh Free Cash Flow dan Harga Saham Terhadap Nilai Perusahaan Dengan Kebijakan Dividen Sebagai Variabel Intervening. Prosiding Seminar Nasional Pakar. 